InOdia $\quad \begin{aligned} & \text { InMedia } \\ & \text { The French Journal of Media Studies }\end{aligned}$

7.1. $\mid 2018$

Visualizing Consumer Culture

\title{
Visualizing Consumer Culture, Commodifying Visual Culture : Spectacles of the Consumer Society
}

\section{Claire Dutriaux and Clémentine Tholas}

\section{(2) OpenEdition \\ 12 Journals}

\section{Electronic version}

URL: http://journals.openedition.org/inmedia/1497

DOI: 10.4000/inmedia.1497

ISSN: 2259-4728

\section{Publisher}

Center for Research on the English-Speaking World (CREW)

\section{Electronic reference}

Claire Dutriaux and Clémentine Tholas, « Visualizing Consumer Culture, Commodifying Visual Culture : Spectacles of the Consumer Society », InMedia [Online], 7.1. | 2018, Online since 20 December 2018, connection on 08 September 2020. URL : http://journals.openedition.org/inmedia/1497; DOI : https:// doi.org/10.4000/inmedia.1497

This text was automatically generated on 8 September 2020

(C) InMedia 


\title{
Visualizing Consumer Culture, Commodifying Visual Culture : Spectacles of the Consumer Society
}

\author{
Claire Dutriaux and Clémentine Tholas
}

1 In London, from May to October 1851, countless shoppers and strollers walked the aisles of the Crystal Palace, specially designed and built to house the Great Exhibition of the Works of Industry of All Nations, to admire the displays of commodities which had been mostly produced in Great Britain and its colonies-representing more than half of the exhibited consumer goods. The Crystal Palace was an architectural feat, an aweinspiring structure of glass and iron; as for the Great Exhibition, it quickly became a defining moment for the British nation in the nineteenth century, between the battle of Waterloo in 1851 and the Diamond Jubilee in 1897, as Jeffrey A. Auerbach outlined in The Great Exhibition of 1851: A Nation on Display (1999). None of the goods in the glass structure were for sale, but visitors could admire them at will-the showcased goods were mostly middle-class commodities such as cutlery, furniture, and clothing, as well as industrial inventions and machinery meant to show how Great Britain advanced towards its future.

2 It is this direct link between the spectacular representation of consumer goods and the desires of spectators that led Thomas Richards in The Commodity Culture in Victorian England to argue that the Exhibition "systematized the representation of commodities" 1 by moving everyday products away from their sites of production solely for the purpose of placing them on display-thus emphasizing their aesthetic value over their monetary value or their usage. Such systematized representation was not addressed only to British visitors. Paul Young described in Globalization and the Great Exhibition how one consequence of the event was, intendedly or unintendedly, to project a world picture of consumer culture and international trade, revolving around Great Britain as the Workshop of the World. The Great Exhibition was a notable moment in the history of the world when commodities were turned into fetishes, creating a bridge between the object and the desiring eye of the consumer. According to Thomas Richards, the 
Great Exhibition signaled the beginnings of "the era of the spectacle," as exhibited commodities pointed to further aesthetic, political, commercial or class meanings. ${ }^{2}$ Consequently, as early as 1899 , the visual implications of consumer society were theorized by American economist Thorstein Veblen, who introduced the notion of "conspicuous consumption" in The Theory of the Leisure Class. He emphasized the connection between the public display of wealth and the desire to attain social prestige or maintain a given social status, as well as the competition, strategies and hierarchies deriving from the demonstration of opulence. ${ }^{3}$ This early observation was then broadened by Guy Debord who developed his concept of the "society of spectacle," in which the consumer society was organized around the production and consumption of images and commodities.

3 The intensification of consumerism during the twentieth century was further analyzed by Emily Rosenberg who concentrated on the United States. She stated that the absence of hereditary nobility and of a rigid class system in America enabled the emergence of an ethos of material acquisition which became the dominant indicator of social standing. The acquisition and exhibition of commodities became as a sign of personal advancement, and mass consumption and entertainment shaped an American dream related to upward mobility and wealth. Consumption offered a semiotics both of inclusion and exclusion within the imagined American community and raised the issue of the relations between the Haves and the Have Nots. Leisure and products of consumer culture helped define a certain idea of democracy and contributed to erasing certain ethnic and class divisions to create a "Republic of consumers". From the 1920 s onwards, consumerism represented a form of material democracy, as all Americans could purchase goods previously enjoyed only by the upper classes. In fact, shared consumer habits unified Americans, and reduced their ethnic, economic, and regional differences. Purchasing was fancied as a way to pursue happiness and attain equality. Advertisers went as far as promoting that consuming was not an empty, materialistic gesture but a civic activity. When shopping, Americans were expressing support for some companies, exercising and gaining rights and consumer capitalism could offer a new freedom-freedom of choice. ${ }^{4}$

4 A number of academics and thinkers have thus argued that consumption has increasingly defined and transformed society, not only in America but in the entire Western world, over the past two centuries. Among these thinkers is Jean Baudrillard with The Consumer Society: Myths and Structures, published in 1970, two years after his seminal study Le Système des objets (1968). In 1970, Baudrillard offered a sociology of consumer society, and argued that commodities were projections of the desires of the individuals rather than true ownership. Baudrillard pointed out how consumption acquired a symbolic dimension and was turned into commodity fetishism, representing a modern, unifying and critical myth: "Consumption is a myth. That is to say, it is a statement of contemporary society about itself, the way our society speaks about itself". ${ }^{5}$ As Baudrillard remarked later in the book, the consumer society is not only involved with consuming (buying and using commodities), otherwise there would be no tale to tellbut it is fundamentally involved with a discourse about society itself, a myth which structures the global world, and allows for social integration. By owning goods, one becomes socially integrated, which means that one reaches happiness. Using its own repetitive codes in which the signifier prevails upon the signified, the visual display of commodities encourages contemporary societies to replicate social models that can be readily consumed and traded. Fashion, which Pierre Bourdieu examined in Questions de 
sociologie, is a good example of this, as commodities which are first appropriated by the elite gradually make their way to the middle-class and then the working-class, which starts a new fashion cycle. It is the idea of owning something, which is first unattainable but desired in order to fit in with the more affluent, which is at the core of the myth of the consumer society.

The contributors to this issue discuss this fundamental myth of the consumer society, whose contours and occurrences in the contemporary world they seek to map. The aim of this set of articles is to examine the links that are made between visual culture and consumer culture and between images and consumer goods, and outline how these links illuminate the society of the spectacle in the twentieth and twenty-first centuries, which were marked by the increased use of various media-from the cinema to the television and the internet. This special issue raises the following questions : How have the imagery and imaginary of our consumption practices evolved over time? What kinds of displays and representational systems prevail in our consumer society? How does this society reflect on itself through visual culture? What are the national and transnational stakes of such mises-en-scène, particularly in the English-speaking world? How did the transformation of mass media beget new codes, power relations and consuming habits? How do industries and companies appropriate the tools of visual culture to promote and display their products?

Recently, geographer Michel Lussault has revisited the meaning and function of the shopping mall which today epitomizes the concentration and exhibition of consumer goods. In Hyper-Lieux: Les nouvelles géographies de la mondialisation, he argues that malls can connect and reunite people from all social classes and identity groups, thus offering a concentration of social reality. They could be understood as modern places of communion in today's globalized society. Lussault doesn't criticize consumerism but observes that people are attracted to places where they gather around a common aspiration. For him, shopping malls are designed not only as places of consumerism but also as loci of entertainment and attraction, and today they can even become a tourist destination, like the Mall of America in Bloomington, Minnesota, also called "the Hollywood of the Midwest". This unique mall is supposed to showcase US values and cultures, with a certain sense of spectacle. ${ }^{6}$ Lussault emphasizes the new meaning of emblematic places of consumer culture and how they transform purchasing activities into experiences of recreational bonding and try to create an artificially unified community of consumers/spectators. Thus today's modern American malls fulfill the same purpose as the Great Exhibition, that of a nation and a society on display.

7 This volume seeks to interrogate the links between consumption, nationhood, and spectacle, extending Lussault's analysis to other modes of representation, geographical locations, and media. Karine Chambefort-Kay studies Martin Parr's perception of British national tastes and consumer psyche in Signs of the Times : a Portrait of the Nation's Tastes (1995). Chambefort-Kay explains that the photographer's work operates both as an explanation of the motivations to buy certain items but also as a strong criticism of over-consumption. Martine Lambert-Charbonnier focuses on the opening ceremony of the 2012 Olympic Games in London, which was created by filmmaker Danny Boyle. Lambert-Charbonnier argues that the show conformed to the Olympic ethos and presented evolving images of British cultural and technological contributions. Lambert-Charbonnier demonstrates that Boyle used symbols which promoted British values, which were then spread across cultural borders as part of British nation- 
building. Emilie Cheyroux surveys the consuming habits of Latinos and their desire to be part of US consumer culture with a close analysis of two major documentaries, Shopping to Belong (Irene Sosa, 2007) and ¿Tacos o Tacos? (Robert Lemon, 2011). She addresses the issues of assimilation and hybridization, arguing that Latinos contribute to the economy and the culture of the United States, which allows them to integrate American society while reinforcing their original cultural identity.

Beyond the spectacle of nationhood, if a commodity is society's mirror of itself, one may also wonder how visual displays of commodities further install dominant ideologies. Douglas Kellner delineated the contours of the spectacle of McDonald's in Media Spectacle by making the case that when Americans bite into a Big Mac, they also bite into the spectacle: "Thus, when one bites into a Big Mac one is consuming the sign values of good times, communal experience, consumer value and efficiency, as well as the (dubious) pleasures of the product." Consumers may also perceive that visual displays of commodities provide a mise en abyme that directs the eye to the constructed character of the myth. For instance, when the design of commodities such as Mondrian-inspired tote bags or Klimt-inspired clothing link the art world with trade and high culture with low culture, such goods foreground the idea that high culture needs to be translated into an object of desire to become accessible to the middle-class and the working-class. In the process, one may wonder whether these consumer goods can still be considered to be works of art, or whether these consumer goods become works of art on the same grounds as the original artwork. When famous movie directors create commercials for consumer goods or services, they imprint their specific film style over the commodity that is advertised and later traded, while at the same time drawing attention to the spectacle of the consumer society. For example, Wes Anderson filmed a commercial for American Express in which he staged himself in the process of shooting a movie, directing the attention of the viewer to the constructedness of the spectacle of commodities-especially since the product, American Express, is never expressly pictured in the commercial.

9 The contributors to this volume examine the ways in which such visual displays of consumption either install, accommodate, or criticize dominant ideologies, especially in gender terms. Thibaut Clément's analysis of the Disney theme parks explores the celebration of consumption in the parks and the development of commercial partnerships with companies whose products are promoted there. Clément argues that the presence of brand names could impact the design and operation of the parks and attractions. Over the years, US corporations have become part of the landscape of Disney parks and consumption is consubstantial with the entertainment experience. Eléonore Obis's article discusses the way wine labels help target specific customers and participate in creating an identity for Californian wines. They reveal the expectations of the customers regarding a certain sense of tradition and terroir but also new tastes, as labels introduce elements from popular culture which can appeal to consumers. Obis contends that Californian wine labels today promote a return to nature, so as to emphasize the authenticity and quality of wines. Alice Morin explores perfume editorials in high-end fashion magazines of the 1970s, and shows that perfumes were used, as displays, to negotiate the tensions of the troubled 1970s and particularly women's emancipation. Morin shows that perfumes thus opposed traditional mechanisms of commodification in that decade. Anne Lesme's work on American Dolls offers an observation of material culture in the US. The production and circulation of these dolls by Mattel questions the construction of a certain sense of history and vision 
of girlhood. To conclude this volume, Stéphanie Mercier's article explores the commodification of women in the plays of Shakespeare, the issue of prostitution and the representation of the brothel as a central place of commercial exchanges, new identity boundaries and power struggles in the early modern city. Mercier's article powerfully echoes Lussault's contemporary preoccupations with "hyper-places" in today's globalized world-showing how the Shakespearean stage worked as one of the first mass media tools involved in the myth of consumerism-and perhaps as a first example of a "hyper-place" well before the advent of globalization.

\section{BIBLIOGRAPHY}

Auerbach, Jeffrey A. The Great Exhibition of 1851 : A Nation on Display, New Haven and London : Yale University Press, 1999.

Baudrillard, Jean. The Consumer Society : Myths and Structures, London, Paris and Los Angeles : Sage Publications, Revised edition, 2017 [1970].

Bourdieu, Pierre. Questions de sociologie, Paris : Editions de Minuit, 1980.

Debord, Guy. La Société du spectacle, Paris : Gallimard, 1992 [1967].

Kellner, Douglas. Media Spectacle, London and New York : Routledge, 2003.

Lussault, Michel. Hyper-lieux : Les nouvelles géographies de la mondialisation, Paris : Seuil, 2017.

Richards, Thomas. The Commodity Culture of Victorian England, Stanford : Stanford University Press, 1990.

Rosenberg, Emily S.. «Le « modèle américain » de la consommation de masse », Cahiers d'histoire. Revue d'histoire critique [Online], 108 | 2009.

Veblen, Thorstein. The Theory of the Leisure Class : An Economic Study of Institutions, New York, B. W. Huebsch, 1918 [1899].

\section{NOTES}

1. Thomas, Richards, The Commodity Culture of Victorian England (Stanford: Stanford University Press, 1990), 39.

2. Thomas, Richards, The Commodity Culture of Victorian England, 3.

3. Thorstein Veblen, The Theory of the Leisure Class: An Economic Study of Institutions (New York, B. W. Huebsch, 1918 [1899]), 36-37.

4. Emily S. Rosenberg, "Le " modèle américain " de la consommation de masse ", Cahiers d'histoire. Revue d'histoire critique [Online], 108 | 2009.

5. Jean Baudrillard, The Consumer Society: Myths and Structures (London, Paris and Los Angeles: Sage Publications, Revised edition, 2017 [1970]), 2010. 
6. Michel Lussault, Hyper-lieux: Les nouvelles géographies de la mondialisation (Paris: Seuil, 2017), chap. 2.

7. Douglas Kellner, Media Spectacle (London and New York: Routledge, 2003), 39.

\section{AUTHORS}

\section{CLAIRE DUTRIAUX}

Claire Dutriaux is Assistant Professor in American studies at Université Paris-Sorbonne. Her research interests include American cinema from the beginnings of the Hollywood industry to the contemporary era, focusing more specifically on issues of race and class in the movies. She has published articles and organized conferences on various subjects ranging from Southern films to Westerns.

Clémentine Tholas is an Associate Professor of American history in the English and applied foreign languages department at the Paris III-Sorbonne Nouvelle University, and holds a Ph.D. in American studies. Her research interests focus on early motion pictures in the US, namely on WWI cinematic propaganda and the role of silent films as tools of progressivism. Clémentine Tholas published Le Cinéma américain et ses premiers récits filmiques (2014) and co-edited with Karen A. Ritzenhoff a collective volume entitled Humor, Entertainment, and Popular Culture during World War I (Palgrave, 2015). 